\title{
Potential of white-rot fungi for bioremediation
}

\section{Ronivaldo Rodrigues da Silva}

Instituto de Biociências, Letras e Ciências Exatas. Universidade Estadual Paulista. Rua Cristovão Colombo, 2265. Jardim Nazareth. São José do Rio Preto-SP. Brazil. (CEP 15054-000). E-mail: rds.roni@yahoo.com.br.

\begin{abstract}
Environmental applications of enzymes in biodegradation for preventing pollution by toxic byproducts warrants approaches that can be performed under mild conditions, are economically feasible and can replace the use of chemicals. Technologies involving physico-chemical methods, like incineration, dechlorination and UV oxidation, for waste treatment are not acceptable since they generate a lot of pollutants as by-products. To address these problems, environmental-friendly alternatives are required for bioremediation. In this context, fungal enzymes have emerged as a natural tool to detoxification of pollutants in environment, and the potential to convert toxic substances to less hazardous or non-hazardous forms. However, what are the effective advances by using white-rot fungi for bioremediation? Here, a brief discussion about the application of these fungi to detoxification of pollutants in environment has been considered.
\end{abstract}

Keywords: Biodegradation; Microbial enzymes; Oxidoreductases.

Resumo. Uso potencial de fungos da podridão-branca da madeira para a biorremediação. Aplicações ambientais de enzimas para biodegradação de poluentes justificam estudos que podem ser performados sob condições amenas de reação, são economicamente viáveis e favorecem a substituição ao uso de compostos químicos. Tecnologias envolvendo métodos físicos e químicos para o tratamento de resíduos, como incineração, declorinação e oxidação por UV, não são aceitáveis, uma vez que geram muitos poluentes tóxicos. Para solucionar estes problemas, alternativas ecologicamente seguras são requeridas para biorremediação. Neste contexto, enzimas fúngicas têm emergido como uma ferramenta natural para detoxificação de poluentes, e o potencial para converter substâncias tóxicas em compostos menos agressivos ao meio ambiente. Contudo, quais são os efetivos avanços no uso de fungos da podridão-branca da madeira para biorremediação? Aqui, uma breve discussão sobre o uso destes fungos para detoxificação de poluentes no ambiente tem sido considerado.

Palavras-chave: Biodegradação; Enzimas microbianas; Oxidorredutases.

\section{Introduction}

Environmental applications of enzymes in biodegradation for preventing
Recebido:

03/02/2017

Aceito:

27/06/2017

Publicado:

30/06/2017

Acesso Aberto

Artigo completo

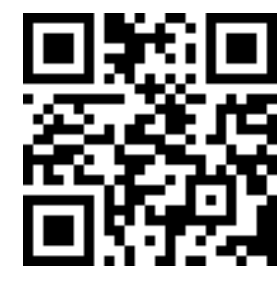

ORCID

(1) 0000-0002-6504-8406 Ronivaldo Rodrigues da Silva pollution by toxic byproducts warrants approaches that can be performed under mild conditions, are economically feasible 
and can replace the use of chemicals (Ahuja et al., 2004).

Technologies involving physicochemical methods, like incineration, basecatalyzed dechlorination and UV oxidation, for waste treatment are not acceptable since they generate a lot of pollutants as byproducts (Karigar and Rao, 2011). For this reason, environmental-friendly alternatives are required for biodegradation of products generated due to anthropogenic activities.

The use of microbial enzymes in bioremediation has gained great popularity in the scientific world and has been extensively explored in the past few years. In this context, the fungi have emerged as a natural tool in bioremediation, due to their enormous capacity of detoxification of pollutants in environment, and the potential to convert toxic substances to less hazardous or non-hazardous forms (Ahuja et al., 2004; Tisma et al., 2010).

However, what are the effective advances by using white-rot fungi for bioremediation? In the current conjecture, what are the future prospects in this sector? Here, a brief discussion about the application of these fungi to detoxification of pollutants in environment has been considered.

\section{Potential of white-rot fungi for bioremediation}

White-rot fungi are well-known fungi explored in bioremediation, due to their capacity for degradation of complex chemical compounds. The ability to detoxification of pollutants in environment is especially true due their capacity to secrete oxidoreductases enzymes, like laccases, manganese peroxidase, and lignin peroxidase.

Studies have demonstrated the potential of white-rot fungi to degrade recalcitrant molecules (Deroy et al., 2015; Silva, 2017; Silva et al., 2017). The valuable repertoire of oxidative enzymes secreted by white-rot fungi are required for biodegradation of chemical compounds, derived from industrial and agricultural activities (Arora and Sharma, 2010). The Table 1 shows some examples by using white-rot in bioremediation.

The metabolic potential of fungi has been explored for bioremediation of xenobiotic polymers, such as petroleum hydrocarbons, organochlorine pesticides, and chemical dyes (Vaithanomsat et al., 2010). White-rot fungi can also serve as promising candidates for treatment of waste effluents derived from textile, coal, alcohol distilleries, pulp, and paper industries (Arora and Sharma, 2010).

In the literature, several studies have demonstrated the bioprospecting potential of white-rot fungi, which act as biodegrading agents. The potential of Phanerochaete chrysosporium fungus in decolorization of synthetic azo dye, which is extensively used in textile industry, has been demonstrated (Senthilkumar et al., 2014). Mtui (2007) described the oxidative effect of crude enzyme extract from Crepidotus variabilis to remove up to $58 \%$ and $92 \%$ color from raw textile effluent and aromatic dyes. In this work, the potential of enzymatic extract to oxidize rhemazol brilliant blue-R (RBB-R) dye, phenol, $\alpha$ naphthol, and pyrogallol was also demonstrated.

The fungus Datronia sp. KAPI0039 was implicated in decolorization of two reactive dyes, Reactive Blue 19 (RBBR) and Reactive Black 5 (RB5) (Vaithanomsat et al., 2010). The capacity of degradation of aflatoxin B1 and organochlorine pesticides by laccases from white-rot fungi Peniophora sp. and Pleurotus ostreatus has been demonstrated (Tekere et al., 2002; Gondim-Tomaz et al., 2005; Kanaly and Hur, 2006; Alberts et al., 2009). The fungi Coriolus versicolor, Hypholoma fasciculare, and Stereum hirsutum demonstrated a great potential in degradation of pesticides, such as diuron, atrazine, and terbuthylazine, with over $86 \%$ removal during 42 days of growth (Bending et al., 2002). 
Table 1. Applications of white-rot fungi in bioremediation.

\begin{tabular}{|c|c|c|c|}
\hline White-rot fungi & Bioremediation process & $\begin{array}{l}\text { Anthropogenic } \\
\text { activity }\end{array}$ & Reference \\
\hline Phanerochaete chrysosporium & $\begin{array}{l}\text { Decolorization of synthetic } \\
\text { azo dye. }\end{array}$ & Textile industry & $\begin{array}{l}\text { Senthilkumar } \\
\text { et al. (2014) }\end{array}$ \\
\hline Crepidotus variabilis & $\begin{array}{l}\text { Decolorization of raw textile } \\
\text { effluent and aromatic dyes. } \\
\text { Oxidation of oxidize rhemazol } \\
\text { brilliant blue-R (RBB-R) dye, } \\
\text { phenol, } \alpha \text {-naphthol, and } \\
\text { pyrogallol. }\end{array}$ & Textile industry & Mtui (2007) \\
\hline Datronia sp. KAPI0039 & $\begin{array}{l}\text { Decolorization of Reactive } \\
\text { Blue } 19 \text { (RBBR) and Reactive } \\
\text { Black } 5 \text { (RB5). }\end{array}$ & Textile industry & $\begin{array}{l}\text { Vaithanomsat } \\
\text { et al. (2010) }\end{array}$ \\
\hline $\begin{array}{l}\text { Peniophora sp. } \\
\text { Pleurotus ostreatus }\end{array}$ & $\begin{array}{l}\text { Degradation of aflatoxin B1 } \\
\text { and organochlorine pesticides. }\end{array}$ & Agriculture & $\begin{array}{l}\text { Tekere et al. } \\
\text { (2002); } \\
\text { Gondim- } \\
\text { Tomaz et al. } \\
\text { (2005) }\end{array}$ \\
\hline $\begin{array}{l}\text { Coriolus versicolor } \\
\text { Hypholoma fasciculare } \\
\text { Stereum hirsutum }\end{array}$ & $\begin{array}{l}\text { Degradation of pesticides } \\
\text { (diuron, atrazine, and } \\
\text { terbuthylazine). }\end{array}$ & Agriculture & $\begin{array}{l}\text { Bending et al. } \\
\text { (2002) }\end{array}$ \\
\hline $\begin{array}{l}\text { Phlebia tremellosa } \\
\text { Phlebia brevispora } \\
\text { Phlebia acanthocystis }\end{array}$ & $\begin{array}{l}\text { Remotion of organochlorine } \\
\text { pesticides, heptachlor and } \\
\text { heptachlor epoxide. }\end{array}$ & Agriculture & $\begin{array}{l}\text { Xiao et al. } \\
(2011)\end{array}$ \\
\hline
\end{tabular}

In another study, Xiao et al. (2011) evaluated the capacity for degradation of organochlorine pesticides, heptachlor and heptachlor epoxide, using white-rot fungi. After 14 days of incubation, the investigators observed the remotion of heptachlor for about $71 \%$ for Phlebia tremellosa, 74\% by Phlebia brevispora and $90 \%$ by Phlebia acanthocystis.

\section{Concluding remarks for future prospects}

White-rot fungi have a notable ability to secrete enzymes of industrial interest. Particular attention has been emerged in the use of these fungi for mycoremediation of toxic compounds.

In this brief report, a discussion about environmental applications of whiterot fungi in biodegradation has been proposed. Exploring the biotechnological potential of these fungi is fundamental to the sustainable industrial development, by which the biodegradation of products generated due to anthropogenic activities can be performed under mild conditions and can replace the use of chemicals.

Thus, motivated by the enormous biochemical variety of white-rot fungi to secrete oxidative enzymes, a reviewed approach about their relevance for technology enzyme reinforces the proposal of this work. Additionally, in the global context, the integrated retrospective about the biotechnological potential of white-rot fungi paves the way for technological innovation and perspective for novel applications in bioremediation.

\section{Conflicts of interest}

Author declare that they have no conflict of interests.

\section{References}

Ahuja, S. K.; Ferreira, G. M.; Moreira, A. R. Utilization of enzymes for environmental applications. Crit. Rev. Biotechnol., v. 24, No. 2/3, p. 125-154, 2004. https://doi.org/10.1080/07388550490493726 
Alberts, J. F.; Gelderblom, W. C. A.; Botha, A.; Van Zyl, W. H. Degradation of aflatoxin $B_{1}$ by fungal laccase enzymes. Int. J. Food Microbiol., v. 135, No 1, p. 47-52, 2009. https://doi.org/10.1016/j.ijfoodmicro.2009.07.022

Arora, D. S.; Sharma, R. K. Ligninolytic fungal laccases and their biotechnological applications. Appl. Biochem. Biotechnol., v. 160, No 6, p. 1760-1788, 2010. https://dx.doi.org/ 10.1007/s12010-009-8676-y

Bending, G. D.; Friloux, M.; Walker, A. Degradation of contrasting pesticides by white rot fungi and its relationship with ligninolytic potential. FEMS Microbiol. Lett., v. 121, No 1, p. 59-63, 2002. https://dx.doi.org/ 10.1111/j.1574-6968.2002.tb11245.x

Deroy, A.; Saiag, F.; Kebbi-Benkeder, Z.; Touahri, N.; Hecker, A.; Morel-Rouhier, M.; Colin, F.; Dumarcay, S.; Gérardin, P.; Gelhaye, E. The GSTome Reflects the Chemical Environment of White-Rot Fungi. Plos One, v. 10, p. 1-13, 2015. https://dx.doi.org/10.1371/journal.pone.0137083

Gondim-Tomaz, M. A.; Franco, T. T.; Durrant, L. R. Biodegradation of diuron and pyruthiobacsodium by white-rot and soil fungi. In: Calabrese, E. J.; Kostecki, P. T.; Dragun, J. (Eds.). Contaminated soils, sediments and water. Boston: Springer, 2005. (Science in the Real World, v. 9). p. 21-32. https://dx.doi.org/10.1007/0-387-23079-3_3

Kanaly, R.; Hur, H. Growth of Phanerochaete chrysosporium on diesel fuel hydrocarbons at neutral pH. Chemosphere, v. 63, No 2, p. 202-211, 2006. https://dx.doi.org/ 10.1016/j.chemosphere.2005.08.022

Karigar, C. S.; Rao, S. S. Role of microbial enzymes in the bioremediation of pollutants: a review. Enzyme Research, v. 2011, Article ID 805187, p. 1-11, 2011. https://dx.doi.org/10.4061/2011/805187

Mtui, G. Characteristics and dyes biodegradation potential of crude lignolytic enzymes from white-rot fungus Crepidotus variabilis isolated in coastal Tanzania. Tanz. J. Sci., $\quad$ v. 33, $\quad$ p. 79-91, 2007. http://dx.doi.org/10.4314/tjs.v33i1.44278
Senthilkumar, S.; Perumalsamy, H.; Prabhu, J. Decolourization potential of white-rot fungus Phanerochaete chrysosporium on synthetic dye bath efluente containing Amido black 10B. J. Saudi Chem. Soc., v. 18, No 6, p. 845-853, 2014. https://dx.doi.org/10.1016/j.jscs.2011.10.010

Silva, R. R. Bacterial and fungal proteolytic enzymes: production, catalysis and potential applications. Appl. Biochem. Biotechnol., p. 1-19, 2017. https://dx.doi.org/10.1007/ s12010-017-2427-2

Silva, R. R.; Oliveira, L. C. G.; Juliano, M. A.; Juliano, J.; Rosa, J. C.; Cabral, H. Activity of a peptidase secreted by Phanerochaete chrysosporium depends on lysine to subsite $S^{\prime}{ }_{1}$. Int. J. Biol. Macromolec., v. 94, pt. A, p. 474-483, 2017. https://doi.org/10.1016/j.ijbiomac.2016.10.063

Tekere, M.; Ncube, I.; Read, J. S.; Zvauya, R. Biodegradation of the organochlorine pesticide, lindane by a sub-tropical white-rot fungus in batch and packed bed bioreactor systems. Environ. Technol., v. 23, No 2, p. 199-206, 2002. http://dx.doi.org/10.1080/09593332508618422

Tisma, M.; Zelic, B.; Vasic-Racki, D. White-rot fungi in phenols, dyes and other xenobiotics treatment - a brief review. Croat. J. Food Sci. Technol., v. 2, n. 2, p. 34-47, 2010. Available from: $\quad<$ http://hrcak.srce.hr/file/97983>. Accessed on: Feb. 24, 2017.

Vaithanomsat, P.; Apiwatanapiwat, W.; Petchoy, O.; Chedchant, J. Production of ligninolytic enzymes by white-rot fungus Datronia sp. KAPI0039 and their application for reactive dye removal. Int. J. Chem. Eng., v. 2010, Article ID 162504, p. 1-6, 2010. https://dx.doi.org/10.1155/2010/162504

Xiao, P.; Mori, T.; Kamei, I.; Kondo, R. Metabolism of organochlorine pesticide heptachlor and its metabolite heptachlor epoxide by white rot fungi, belonging to genus Phlebia. FEMS Microbiol. Lett., v. 314, No. 2, p. 140146, 2011. https://doi.org/10.1111/j.15746968.2010.02152.x

License information: This is an open-access article distributed under the terms of the Creative Commons Attribution License, which permits unrestricted use, distribution, and reproduction in any medium, provided the original work is properly cited. 